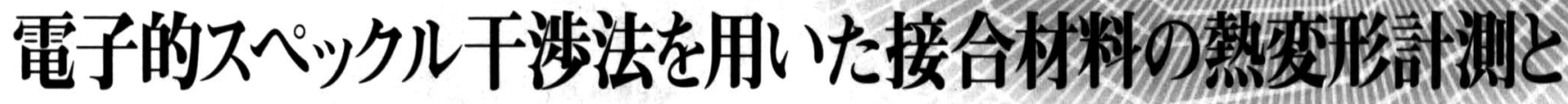 ヒルベル変換法による高精度位相解析*
}

\section{門野博史 **}

Thermal Expansion Studies of Joint Material Using ESPI and Hilbert Transform Method for High Precision Phase Analysis / Hirofumi KADONO

Key words: electronic speckle pattern interferometry, joint material, thermal expansion, hilbert transform method, phase analysis

\section{1. はじめに}

物体の変形, ひずみ計測は様々な構造物, 工業部品・材 料の設計, 信頼性評価, 品質管理, 安全管理などにおいて 不可欠である。また, 年々高機能化, 高精密化する最先端 の工業部品において要求される精度はミクロンオーダにと どまらず場合によってはナノメートルの精度が要求され る. 対象とする物体の大きさは MEMS に代表される数ミ クロン程度の微小構造体から自動車, 飛行機, 建物, 橋梁 に至る巨大構造物まで様々である。このように微小物体か ら大構造物に対して適用可能で高精度な変形, ひずみ計測 の要求に応えられる技術として干渉計測法がある ${ }^{1)}$. 従来 の干渉法は, ミラーやレンズなど表面粗さが光の波長に比 べて十分に小さく, 光学的に鏡面にの及適用可能であり, 応用範囲は光学部品など特殊な用途に限定されていた。

これに対して, スペックル干渉法と呼ばれる一連の計測 技術 ${ }^{2)}$ ） 考用いると物体表面に対する従来の制限がなく なり, かつ光干渉法で一般的に実現可能な高い計測精度を 保ちつつ, 光学的に粗い物体に対して干渉法が適用可能と なる。このようにスペックル干渉法は極めて実用性の高い 干涉技術である. 本稿では, 物体の熱変形計測に焦点を絞 り，スペックル干渉法を適用する際の問題点ならびに最近 著者らが提案した Hilbert 変換法による高精度位相解析 ${ }^{4)}$ について解説する。

\section{2. スペックル干渉法}

レーザ光のようなコヒーレントな光で粗面物体や散乱媒 質を照射すると，图１に示すように，物体の回折界や像界 にぎらぎら輝くコントラストの高いランダムな斑点模様の

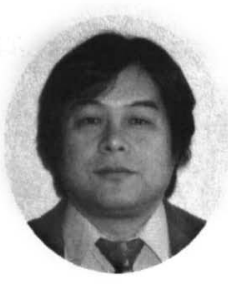

•原稿受付 平成 16 年 10 月 13 日

**埼玉大学(さいたま市桜区下大久保 255) 門野博史

1997 年北海道大学大学院理工学研究科博士後期 課程修了. 工学博士. 91 年埼玉大学工学部助教 授. 95 年同大学院理工学研究科環境制御工学専 攻助教授、専門は、光計測、統計光学など、特 にレーザースペックルを用いた干渉計測
パターンが容易に観測される。これがレーザスペックルと 呼ばれるパターンであり, 物体により散乱された光がラン ダムに干渉することにより生じるものである ${ }^{6)}$.レーザス ペックルはその成因から明らかなように，物体に対する 様々な情報を持っており, これまでに表面粗さ計測, 速度 計測，さらに干涉光学系を用いることにより高精度な物体 の変形計測, ひずみ計測, 振動計測などの応用計測が種々 提案されてきた. 後者の干涉光学系を用いた計測法がスぺ ックル干渉法と呼ばれている。

図 2 に一般的に用いられる電子的スペックル干涉法 (ESPI)による面外変形計測光学系を示す。レーザ光はビー ムスプリッタにより 2 つに分けられ, 基準となる物体およ

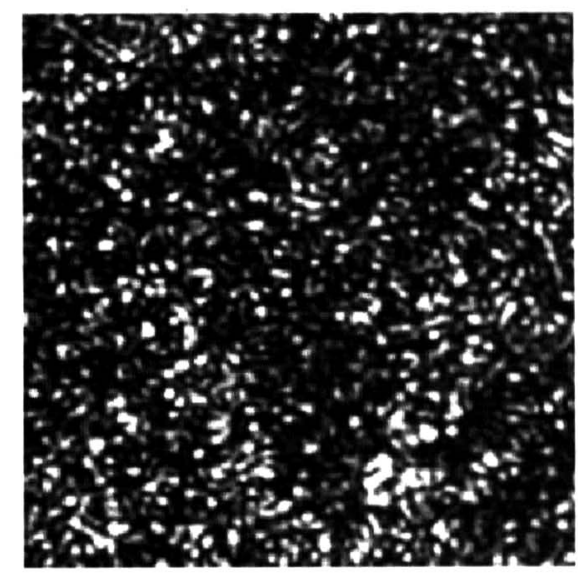

図1 スペックルパターン

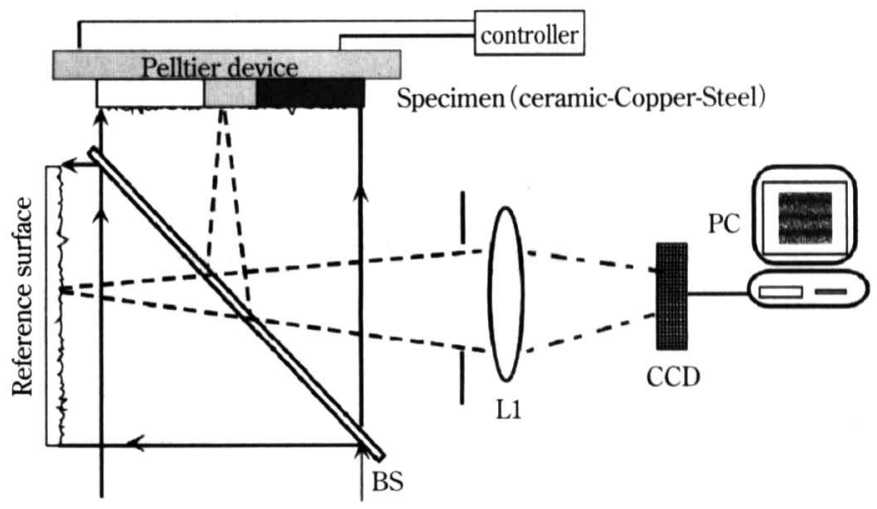

図 2 スペックル干渉法による面外変形計測光学系 


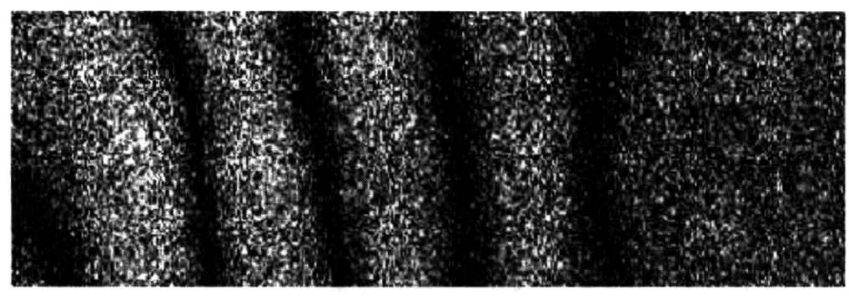

図 3 ESPIにより得られたスペックル相関縞

び被検物体を照明する。それぞれの表面で散乱された光は

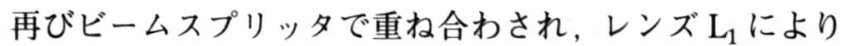
CCD カメラ上に結像される。観察される画像は，それぞ れの物体により発生した 2 つススペクルパターンのラン ダムな干渉画像として次式で表される。

$I(x, t)=I_{0}(x, t)+I_{m}(x, t) \cos [\theta(x, t)+\phi(x, t)](1)$ ここで, $x$ は物体面上での座標である. $I_{0}, I_{m}$ はそれぞれ バイアス強度および変調強度である。また， $\theta, \phi$ はそれ ぞれ空間的にランダムなスペックル位相および物体の面外 変形に起因する光路変化による物体位相である。ここで物 体の変形前後 $\left(t=t_{1}, t_{2}\right)$ でスペックル干渉画像の差の絶対 值をとると

$\Delta I\left(x, t_{1}, t_{2}\right)=\left|I\left(x, t_{1}\right)-I\left(x, t_{2}\right)\right|$

$\approx 2 I_{m}\left|\sin \left(\theta\left(x, t_{1}\right)+\Delta \phi\left(x, t_{1}, t_{2}\right) / 2\right) \| \sin \left(\Delta \phi\left(x, t_{1}, t_{2}\right) / 2\right)\right|$

となる。ここで, $\Delta \phi$ は物体の変形に対応し, 物体の面外 変形量を $\Delta h\left(x, t_{1}, t_{2}\right)=h\left(x, t_{1}\right)-h\left(x, t_{2}\right)$ とすると

$$
\Delta \phi\left(x, t_{1}, t_{2}\right)=(4 \pi / \lambda) \Delta h\left(x, t_{1}, t_{2}\right)
$$

で与えられる. 図 3 に ESPIにより物体の変形によって得 られる典型的なスペックル相関縞を示す。 (2)，(3)式より 相関縞 1 本に対応する物体の面外変形量は光の 1 波長であ ることがわかる.

現代の干渉測定法では，干渉縞あるいはスペックル干渉 法では相関縞の 1 本を空間的に補間することにより，波長 の数十分の 1 から数百分の 1 という高感度な計測を実現し ている.これまでに相関縞の解析法としてフーリ工変換法 など種々提案されているが，これらはスペックル相関縞を 空間領域で解析している. スペックル相関縞はランダムな スペックルパターンで変調されており，ESPIでは一般に ノイズの非常に大きな信号を処理しなければならない。こ れは(2)式においてスペックル位相 $\theta(x, t)$ が空間的に急 激に変動していることに起因している。この問題は物体の 変形分布が急激になり相関縞の縞間隔がスペックル粒子と 同程度に近づいてくると顕著になり，高精度位相解析ある いは計算機による自動解析を非常に困難にしてきた。その 結果, 空間分解能はスペックル粒子の平均サイズに比べて かなり粗くなるという欠点がある。

\section{Hilbert 変換法による高精度位相解析}

空間領域での位相解析に伴う問題を解決するために，著 者の研究室では最近スペックル干渉パターンを空間領域で 位相解析をおこなう代わりに, パターン上の各点において時 間領域で位相解析を抢こなう Hilbert 変換法を提案した ${ }^{4)}$. この手法の利点は, 図 4 に示すように観測画面上のある 1

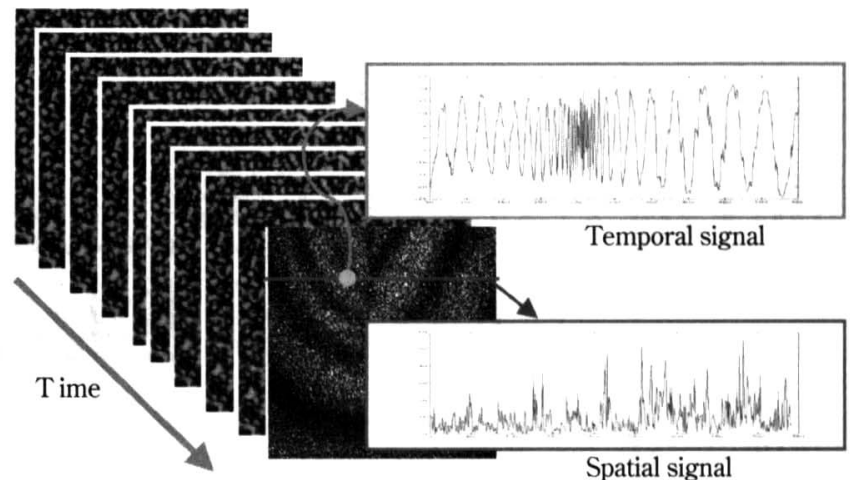

図4 ESPIで得られる空間信号(Spatial signal)と時間信号(Temporal signal) 点での強度に注目すると, 時間領域においてはノイズの少 ない干渉信号が容易に得られることにある。これは，ラン ダムなスペックル位相 $\theta(x, t)$ は時間的には緩やかに変動 する性質をもつことによる.

時間領域において (1) 式を位相解析することにより物体 位相 $\phi(x, t)$ を高精度に解析するために Hilbert 変換を利 用した位相解析法を提案した。実時間信号を $u(t)$ とする とその解析信号 $a(t)$ は

$$
a(t)=u(t)+i v(t)
$$

と表せる，実部と虚部は互いに Hilbert 変換により与えら れる ${ }^{7)}$ 8).すなわち

$$
v(t)=H T\{u(t)\}=\frac{1}{\pi} \int_{-\infty}^{+\infty} \frac{u\left(t^{\prime}\right)}{t^{\prime}-t} d t^{\prime}
$$

により与えられる。ここで重要なことは，

$$
\sin (\varphi(t))=H T[\cos (\varphi(t))]
$$

という性質である。すなわち Hilbert 変換により全周波数 領域で位相を $\pi / 2$ だけシフトさせた信号を得ることがで きる. (1)式よりバイアス強度 $I_{0}$ を取り除いた信号を $I_{\mathrm{c}}(x, t)$ とすると, 求めたい物体位相は次式で与えられる。

$$
\theta(x, t)+\phi(x, t)=\tan ^{-1}\left(\frac{H T\left\{I_{\mathrm{c}}(x, t)\right\}}{I_{\mathrm{c}}(x, t)}\right)
$$

よって $t=t_{\mathrm{o}}$ での位相分布を基準(参照位相分布)として， 時刻 $t$ での位相分布から差し引くと物体の変形量 $\Delta \phi(x, t$, $\left.t_{0}\right)$ は

$$
\begin{gathered}
\Delta \phi\left(x, t, t_{0}\right)=\theta(x, t)+\phi(x, t)-\left\{\theta\left(x, t_{0}\right)+\phi\left(x, t_{0}\right)\right\} \\
\quad \approx \phi(x, t)-\phi\left(x, t_{0}\right)
\end{gathered}
$$

で与えられる。（8)式はスペックル位相の相関が保たれる 限り成り立つ。言い換えると非常に大きな変形に対しては スペックルパターン自体が変化し相関が徐々に失われ, 計 測精度が低下する。これを避けるにはスペックルパターン の相関が失われる前に参照点を順次更新すればよい．この 方法はダイナミック ESPI として提案しており ${ }^{5)}$, 物体が 破壊に至るまでの過程の観察を可能にしている。ここで紹 介した Hilbert 変換法による位相解析では, およそ光の波 長の 20 分の 1 程度の精度を得ることができる.

\section{4. 実験一接合材料の熱ひずみ計測一}

まったく異なった性質を示す 2 種類の材料を接合し，新 しい接合体を作製することにより，2つの材料の性質を合 


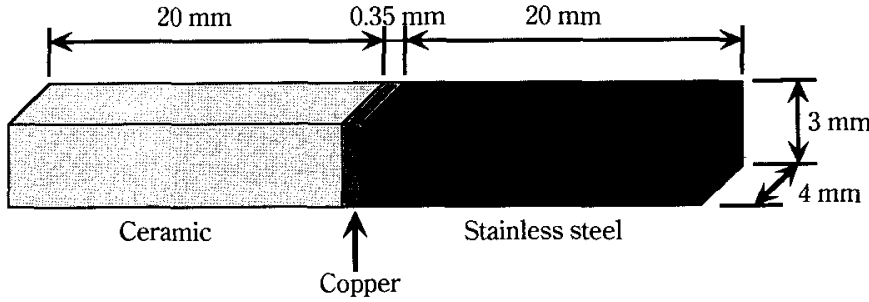

図 5 実験に用いた接合材料

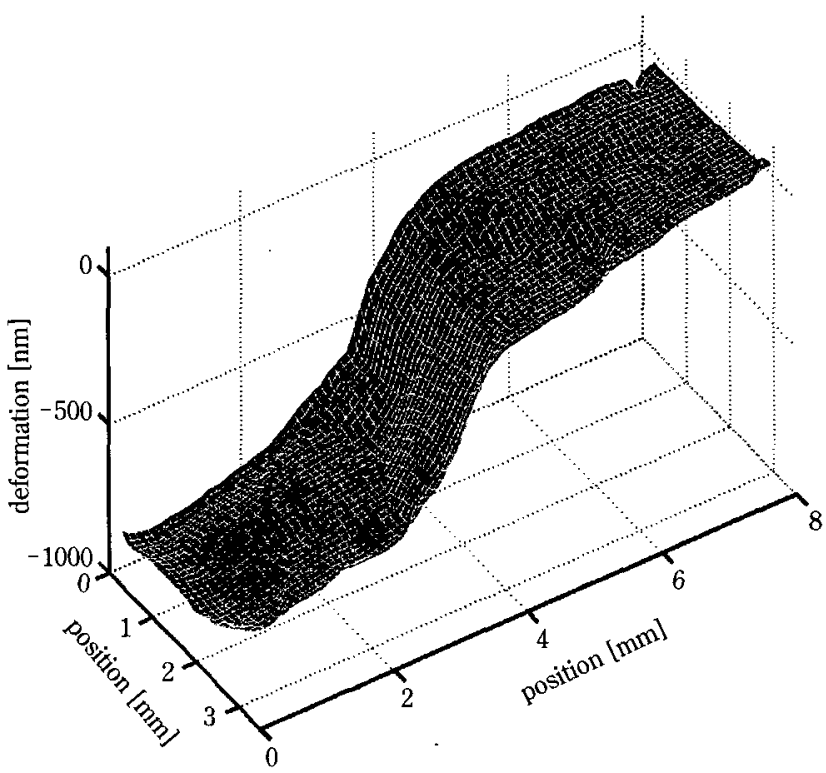

図 6 接合材料の面外熱変形

わせもつ新材料や新しい機能素子が誕生する。また接合に よって，一方の材料の状態を変え，その材料自身の性質を 向上させたり，さらには新しい機能を付け加えることがで きる。近年，産業界において，各種接合材料の重要性はま すます增大し，その技術はいろいろな製品に応用されてい る，接合する材料の線膨張係数が大きく異なると，接合面 に大きなひずみが集中し最悪の場合には破壊に至る。した がって接合境界付近での変形・ひずみ分布の計測は新材料 開発にとって非常に重要である。

本稿では, セラミックスとステンレスを薄い銅の層を挟ん で接合した材料の接合界面付近での熱変形の計測を紹介す る. 被検試料の構造を図 5 に示す。 セラミックス，銅，ステ ンレスの線膨張係数はそれぞれ, $3 \times 10^{-6} / \mathrm{K}, 17.7 \times 10^{-6} / \mathrm{K}$, $15 \times 10^{-6} / \mathrm{K}$ である。 セラミックスとステンレスでは 5 倍の 差がある。

\section{1 面外熱変形の計測}

接合材料の面外変形の計測には，図 2 に示すマイケルソ ンタイプの光学系を用いた。試料はペルチェ素子にマウン

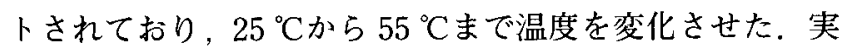
験ではまず， $55{ }^{\circ} \mathrm{C}$ まで加熱した後ぺルチェ素子への電流 を切断し，自然冷却による温度低下に伴う試料の面外の熱

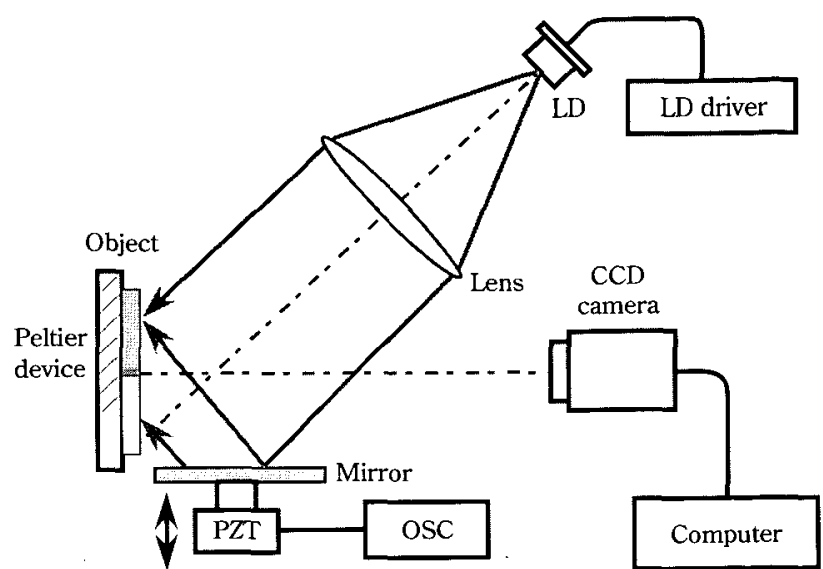

図 7 接合材料の面内熱ひずみ計測の実験系

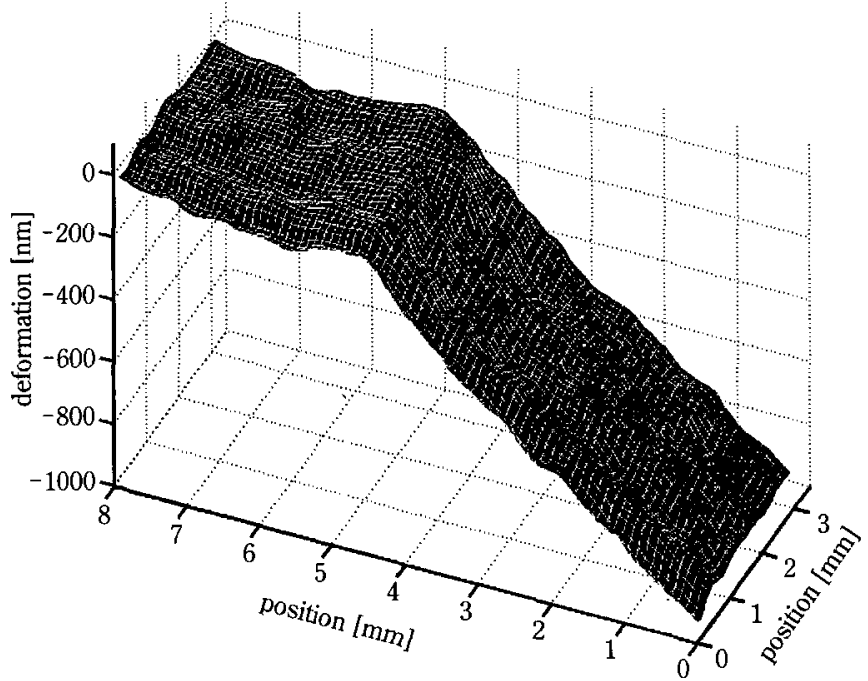

図 8 接合材料の面内変形(接合境界に垂直方向)

変形を観測した。図 6 に $55^{\circ} \mathrm{C} の$ 初期加熱時を基準として 17 秒後の変形分布を示す. 試料上の锶測領域は $3.5 \mathrm{~mm} \times$ $8 \mathrm{~mm}$ である．接合境界は長手方向に $4 \mathrm{~mm}$ の場所に位置 する. 領域 0 約 $4 \mathrm{~mm}$ はステンレスであり, 約 $4 \mathrm{~mm}$ 一 $8 \mathrm{~mm}$ の領域はセラミックスである.

図からわかるように，セラミックス側に比べてステンレ ス側では大きく収縮しており，接合境界から約 $4 \mathrm{~mm}$ の場 所で $900 \mathrm{~nm}$ の変形が生じていることがわかる.

\section{2 面内熱変形の計測}

図 7 に面内変形の計測に用いた光学系を示す. 光源とし て波長 $680 \mathrm{~nm}$ の半導体レーザを用いた。レーザ光はレン ズ(Lens)により平行光となり，ビームの半分は物体法線に 対して $\alpha$ の角度で直接物体を平行光で照明する。一方, 照明ビームの他方の半分はミラー (Mirror)により物体を角 度一 $\alpha$ で照明する. 2 つ照明光によって生じたスペック ルパターンは観察結像系を通して重ね合わされて干渉し， 干渉パターンは CCD カラにより記録される。ここで物 体の接合界面に垂直方向の面内変位を $\Delta x$ とすると $2 つ の$ 光波の間に導入される位相差 $\Delta \phi$ は

$$
\Delta \phi=\frac{4 \pi}{\lambda} \Delta x \sin \alpha
$$


で与えられる。

(1)式の位相項の符号は単純に一枚の観測画像の強度か ら一意に決定することができない。この符号の不確定性を 解決するための一般的な手法は，(1)式の位相項が常に単 調増加となるように付加位相（あるいはしばしばキャリア 成分と呼ばれる)を導入することである。このため光学系

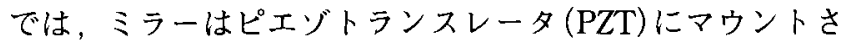
れており，時間的に線形な付加位相 $\omega t$ が導入される.

面外熱変形の計測時と同様に，55 ${ }^{\circ} \mathrm{C}$ まで初期加熱した 後自然冷却による面内の熱変形を計測した。1 17 秒後の変 形計測結果を图 8 に示す。試料への 2 つの照明光が作る 照射平面が接合境界に対して垂直に設定されているため， 接合境界に対して垂直方向の面内変形が計測されている. 図 8 において，接合境界は長手方向 $(\mathrm{x}$ 方向)に約 $5 \mathrm{~mm}$ に 位置する. $0 \mathrm{~mm}$ ～ $5 \mathrm{~mm}$ の領域はステンレスであり，他 方はセラミックスである。図からわかるように，それぞれ の領域において，材料の線膨張係数の違いにより，変形の スロープが著しく䀧なることがわかる，ステンレスとセラ ミックスでは線膨張係数が約 5 倍異なるが，計測された変 形分布の傾きの差はそれよりも大きいことがわかる。これ は，せラミックスの熱伝導率が小さくステンレス側に比べ て表面温度の変化が小さいためであると思われる。

さらに興味深い点は，接合境界で銅層の部分では局所的 に変形の傾きに逆転が見られることである．ステンレスと セラミックスの大きな線膨張係数の差により柔らかい銅層 へ大きな熱ひずみが集中した結果と思われる.

このような面内変位の干渉計測は，鏡面物体に対する従 来の干渉法では実現不可能である。物体からの散乱光を利 用したスペックル干涉法により初めて可能となる計測法で ある。

\section{5.おわりに}

本稿では，スペックル干渉法による熱変形の 2 次元分布 計測と Hilbert 変换法による高精度位相解析法について解 説した。従来，ESPIでは，位相解析は空間領域で扔こな われていたが，本位相解析法では時間領域でおこなうこと
によりスペックルノイズの影響を最小にしている，得られ る精度は $\lambda / 20$ 程度である。ささらに本方法では，観測画像 の各点において独立に物体位相が求めら机るため，物体に 龟裂など不連続な構造がある場合は特に有効である。また， 空間分解能は個々のスペックル粒子が情報の基本単位とな るためスペックルサイズと同程度まで向上する.

ここで紹介したスペックル干涉法以外に，我々が提案し たまったく異なる原理に基づいた統計干渉法 ${ }^{9)}$-12)を用い ると，物体上の 1 点に関してサブナノメートルの精度で変 形，あるいはひずみを $10^{-7}$ strainの精度で計測することが 可能である，詳細は参考文献に譲るが，統計干渉法法超高 精度な測定法であるが，同時に 2 次元分布を得ることはで きない。したがって, 本稿で述べた 2 次元計測法と組み合わ せることによって，必要に応じて柔軟な計測が可能である。

\section{参 考 文 献}

1) P. Hariharan: Optical Interferometry, Academic Press, (1985).

2) R.S. Sirohi (ed.), Speckle Metrology, (Marcel Dekker, Inc., 1993).

3) P. K. Rastogi (Ed.), Photomechanics, (Springer-Verlag, Berlin, 1999).

4) V.Madjarova, H.Kadono, and S.Toyooka, "Dynamic electronic speckle pattern interferometry (DESPI) phase analyses with temporal Hilbert transform", Optics Express, 11, 6, (2003) 617-623.

5) V. Madjarova, S. Toyooka, R. Widiastuti, H. Kadono, "Dynamic ESPI with subtraction-addition method for obtaining the phase," Opt. Commun. 212, (2002) 35-43.

6) Dainty, J. C., ed.: Laser speckle and related phenomena, SpringerVerlag, Berlin, (1975).

7) Stefan L. Hahn, Hilbert Transforms in Signal Processing, Artech House, Boston, (1996).

8) Sanjit K. Mitra, Digital Signal Processing: A computer based approach, McGraw-Hill Companies, Inc., (2002).

9) H. Kadono, and S. Toyooka: "Statistical interferometry based on a statistics of speckle phase," Opt. Lett., 16, (1991) 883-885.

10) H. Kadono, S. Toyooka, and Y. Iwasaki: "Speckle shearing interferometry using a liquid crystal cell as a phase modulator," J. Opt. Soc Am, A8, (1991) 2001-2008.

11）門野博史, 豊岡了: 統計的干涉計測法による高精度変位計測, 光技 術コンタタト, 32-5, (1994) 17-23.

12) H. Kadono, Y. Bitoh, and S. Toyooka: "Statistical interferometry based on fully developed speckle field:An experimental demonstration with noise analysis," J. Opt. Soc. Am A, 18, (2001) 1267-1274. 